\title{
TINJAUAN DAN PANDANGAN HUKUM TERHADAP PERKAWINAN YANG TIDAK TERCATAT PEMERINTAH SERTA DAMPAKNYA SECARA EKONOMI
}

\author{
Tulus Prijanto \\ STIE Swasta Mandiri, Surakarta \\ Email:pritulus7@gmail.com
}

\begin{abstract}
The purpose of this research is to find out how the legal review and views of unregistered marriages by the government are still widely practiced by the community, where if something happens that causes the marriage to be terminated, it will have an impact on several things and one of them is in the form of economic impact (material /legacy). This research is a qualitative research using literature study method which is supported by various relevant references, especially journals related to the research theme. The results showed that marriages that were not registered by the government had a large legal impact, especially on the proceeds of marriage, on the status of the child resulting from marriage. This marriage is valid in the eyes of religion but has no legal force that can harm both women and children, because they cannot make legal claims against the husband when the husband does not provide a living and the husband divorces his wife, and is not even entitled to inheritance if the husband dies. Of course, the economic impact for the wife, especially for their children, is very large. The husband or the father of the child can leave all obligations for all living expenses both to the ex-wife and the child he has left behind. Thus, the ones who will become the biggest economic victims are their offspring from a legal perspective.
\end{abstract}

Keywords: law, marriage under the hands, economics

\section{Pendahuluan}

Perkawinan dilakukan dalam rangka menjalankan sunah Nabi untuk menciptakan kondisi rumah tangga yang penuh ketentraman diantara keduanya. Meskipun hukumnya sunah secara agama, tetapi memiliki timbangan keimanan yang sangat besar sebagaimana sabda Nabi bahwasanya menikah menyempurnakan dari setengah agama. Selain itu dengan melakukan perkawinan atau pernikahan dapat menghindarkan manusia dalam berbuat yang menyimpang dan merusak yang dapat merugikan diri dan orang lain (Brake, 2011); (Asmaya, 2012); (Wibisana, 2016).

Fenomena yang berkembang sekarang banyak terjadi pernikahan yang dilakukan secara agama tetapi tidak tercatat oleh pemerintah (perkawinan sirri) sesuai aturan Undang-undang Perkawinan No. 1 (1974) pasal 2 yang dijabarkan pada ayat 2 (Saebani, 2008); (Subekti, 2010); (Fitrianti, 2017). Pernikahan semacam ini dari sudut pandang hukum negara atau pemerintah yang tertuang dalam undang-undang tentunya berbeda dibandingkan dari sisi hukum agama. Pernikahan yang tercatat pemerintah memiliki kekuatan secara hukum negara jika terjadi 
perceraian, terutama demi melindungi istri atau anak dari hasil perkawinan itu sendiri (Faizah, 2014); (Rodliyah, 2014); (Alfin \& Busyro, 2017).

Maraknya perkawinan yang tidak tercatat pemerintah (kawin sirri) ini dikawatirkan hanya dijadikan modus beberapa orang untuk memuaskan keinginan hawa nafsunya (Islami, 2017). Padahal jika kita kaji sejarah tentang riwayat pernikahan Rasulullah SAW, bahwasanya pernikahan secara agama (sirri) saat itu dilakukan untuk mengembangkan syiar dakwah Islam dan yang lebih penting lagi melindungi perempuan (Suhartatik, 2013); (Badri, 2017).

Dari ulasan pada pendahuluan di atas, maka peneliti sangat tertarik melakukan penelitian dengan judul tinjauan dan pandangan hukum terhadap perkawinan yang tidak tercatat pemerintah serta dampaknya secara ekonomi.

\section{Landasan Teori}

\subsection{Perkawinan}

Perkawinan adalah persekutuan hidup antara seorang pria dan seorang wanita yang dikukuhkan secara formal dengan Undang-Undang, yaitu yuridis dan kebanyakan juga religius menurut tujuan suami istri dan Undang-Undang, dan dilakukan untuk selama hidupnya menurut lembaga perkawinan (Tutik, 2006). Dalam KUH Perdata, pengertian perkawinan tidak dengan tegas diatur ketentuannya seperti Pasal 26 yang memandang perkawinan hanya dalam hubunganhubungan perdata dan Pasal 27 bahwa perkawinan menganut prinsip monogami. Pasal 103 menyatakan bahwa suami dan isteri harus saling setia, tolong menolong dan bantu membantu. Meskipun tidak dijumpai sebuah definisi tentang perkawinan, ilmu hukum berusaha membuat definisi perkawinan sebagai ikatan antara seorang pria dan seorang wanita yang diakui sah oleh perundang-undangan negara dan bertujuan untuk membentuk keluarga yang kekal abadi (Nurhayani, 2015).

Menurut Undang-Undang Perkawinan Nomor 1 Tahun 1974 Pasal 1 ayat 2 perkawinan didefinisikan sebagai : "ikatan lahir batin antara seorang pria dengan seorang wanita sebagai suami isteri dengan tujuan membentuk keluarga, rumah tangga yang bahagia dan kekal berdasarkan Ketuhanan Yang Maha Esa”. Pencantuman berdasarkan Ketuhanan Yang Maha Esa adalah karena negara Indonesia berdasarkan kepada Pancasila sila yang pertama adalah Ketuhanan Yang Maha Esa. Sampai disini tegas dinyatakan bahwa perkawinan mempunyai hubungan yang erat sekali dengan agama, kerohanian sehingga perkawinan bukan saja mempunyai unsur lahir/jasmani tetapi juga memiliki unsur batin/rohani.

Sedangkan menurut Kompilasi Hukum Islam, seperti yang terdapat pada pasal 2 dinyatakan bahwa perkawinan dalam hukum Islam adalah, perkawinan yaitu akad yang sangat kuat atau mitsaqan ghalidhan untuk mentaati perintah Allah dan melaksanakannya merupakan ibadah.

Terkadang masih banyak orang yang ragu-ragu untuk menikah, karena ia sangat takut memikul beban berat dan menghindarkan diri dari kesulitan. Namun Islam telah memperingatkan bahwa dengan kawin, Allah akan memberikan penghidupan yang berkecukupan kepadanya, menghilangkan kesulitannya dan diberikannya kekuatan untuk mengatasi kemiskinan. Allah berfirman dalam Surat An-Nur ayat 32: 
Artinya: "Dan nikahkanlah orang-orang yang sendirian diantara kamu, dan orang-orang yang layak (berkawin) dari hamba-hamba sahayamu yang lelaki dan hamba-hamba yang perempuan. Jika mereka miskin Allah akan memampukan mereka dengan karunia-Nya dan Allah Maha luas (pemberian-Nya) lagi Maha Mengetahui”.

\subsection{Hukum Melakukan Perkawinan}

Hukum Islam mengenal lima kategori hukum yang lazim dikenal dengan sebutan al-ahkam al-khamsah (hukum yang lima) yakni: wajib (harus), sunnah atau mustahab atau tathawwu' (anjuran atau dorongan, atau sebaiknya dilakukan), ibahah atau mubah (kebolehan), karahah atau makruh (kurang atau tidak disukai, sebaiknya ditinggalkan) dan haram (larangan keras) (Suma, 2004).

a. Wajib, yaitu perkawinan yang harus dilakukan oleh seseorang yang memiliki kemampuan untuk menikah (berumah tangga) serta memiliki nafsu biologis (nafsu syahwat) dan khawatir benar dirinya akan melakukan zina manakala tidak melakukan perkawinan. Keharusan perkawinan ini didasarkan atas alasan bahwa mempertahankan kehormatan diri dari kemungkinan berbuat zina adalah wajib.

b. Sunnah, Perkawinan menjadi sunnah bila dilakukan seseorang dipandang dari dipandang dari faktor pertumbuhan jasmaninya sudah wajar dan cenderung untuk kawin. Ia sudah punya kemampuan membiayai hidup sendiri. Baginya melakukan perkawinan sunnah, bila dia kawin menerima pahala, kalau tidak atau belum kawin, dia tidak berdosa.

c. Ibahah atau mubah (kebolehan), Ibahah atau mubah yaitu perkawinan yang dilakukan tanpa ada faktor-faktor yang mendorong (memaksa) atau yang menghalanghalangi. Perkawinan ibahah inilah yang umum terjadi di tengah-tengah masyarakat luas, dan oleh kebanyakan ulama dinyatakan sebagai hukum dasar atau hukum asal dari nikah.

d. Karahah atau makruh (kurang atau tidak disukai, sebaiknya ditinggalkan), Perkawinan dikatakan makruh jika seseorang dilihat dari sudut pertumbuhan jasmani sudah pantas untuk kawin. Namun, ia belum ada kesanggupan untuk membiayai kehidupan keluarga setelah kawin. Dikhawatirkan perkawinannya akan membawa sengsara bagi istri dan anaknya. Orang seperti ini baginya makruh melangsungkan perkawinan. Bila tidak kawin dengan pertimbangan, tidak berdosa. Asal selalu berupaya agar tidak terjerumus berbuat dosa.

e. Haram (larangan keras). Perkawinan berubah menjadi haram jika perkawinan tersebut bertujuan tidak baik menganiaya pasangan. Misalnya, seorang laki-laki hendak mengawini seorang perempuan dengan tujuan menganiaya atau memperolok-olokan istri (perempuan). Maka haram bagi laki-laki itu nikah dengan perempuan tersebut. Perkawinan dengan muhrim perempuan muslim dikawinkan dengan laki-laki nonmuslim, juga haram, begitu pula larangan untuk poliandri.

\subsection{Tujuan Perkawinan}

Tujuan perkawinan adalah membentuk keluarga yang bahagia dan kekal. Untuk itu suami isteri saling membantu dan melengkapi, agar masing-masing dapat mengembangkan kepribadiannya membantu dan mencapai kesejahteraan spiritual dan materiil (Komariah, 2004). Dalam masyarakat adat khususnya yang bersifat kekerabatan tujuan perkawinan adalah untuk 
mempertahankan dan meneruskan garis keturunan, untuk kebahagiaan rumah tangga keluarga/kerabat, untuk memperoleh nilai-nilai adat budaya dan kedamaian dan untuk mempertahankan kewarisan. Sedangkan tujuan perkawinan menurut perintah Allah untuk memperoleh keturunan yang sah dalam masyarakat, dengan mendirikan rumah tangga yang damai dan teratur. Sebagaimana firman Allah dalam Surat An-Nisa ayat 3:

Artinya: "Dan jika kamu takut tidak akan dapat Berlaku adil terhadap (hak-hak) perempuan yang yatim (bilamana kamu mengawininya), Maka kawinilah wanita-wanita (lain) yang kamu senangi : dua, tiga atau empat. kemudian jika kamu takut tidak akan dapat Berlaku adil, Maka (kawinilah) seorang saja, atau budak-budak yang kamu miliki. yang demikian itu adalah lebih dekat kepada tidak berbuat aniaya".

\subsection{Syarat Sahnya Perkawinan}

Undang-undang perkawinan menyatakan bahwa perkawinan adalah sah apabila dilakukan menurut hukum masing-masing agama dan kepercayaan itu (Pasal 2 ayat 1). Dengan penjelasan bahwa tidak ada perkawinan diluar hukum masing-masing agamanya dan kepercayaannya itu, sesuai dengan Undang-Undang Dasar 1945. Yang dimaksud dengan hukum masing-masing agamanya dan kepercayaannya itu sepanjang tidak bertentangan atau tidak ditentukan lain dalam undang-undang ini. Rumusan Pasal 2 ayat 1 beserta dengan penjelasannya itu menerangkan bahwa perkawinan mutlak harus dilakukan menurut hukum masing-masing agamanya dan kepercayaan itu, kalau tidak, maka perkawinan itu tidak sah (Undang-Undang Nomor 1 Tahun 1974).

\section{Metodologi Penelitian}

Penelitian tentang tinjauan dan pandangan hukum terhadap perkawinan yang tidak tercatat pemerintah ini merupakan penelitian kualitatif dengan menggunakan metode studi pustaka yang didukung dengan berbagai referensi yang relevan terutama artikel jurnal dan berbagai buku yang terkait dengan tema penelitian.

\section{Hasil Penelitian}

Undang-Undang Nomor 1 Tahun 1974 tentang Perkawinan, yang termaktub pada Pasal 1 yaitu pengertian perkawinan merupakan suatu ikatan lahir dan bathin antara seorang pria denan seorang wanita sebagai suami istri mempunyai tujuan membentuk suatu keluarga atau rumah tangga yang bahagia dan kekal berdasarkan Ketuhanan Yang Maha Esa.

Perkawinan yang tidak tercatat oleh pemerintah (nikah sirri) merupakan perkawinan yang dilakukan berdasarkan aturan agama atau aturan adat istiadat, tetapi model perkawinan semacam ini tidak dicatatkan kepada pemerintah (Masduqi, 2013). Perkawinan yang tidak tercatat pemerintah atau nikah sirri dalam tinjauan dan pandangan Islam merupakan perkawinan yang dilakukan hanya memenuhi ketentuan mutlak untuk sahnya suatu akad pernikahan yang ditandai dengan adanya calon pengantin (baik laki-laki maupun perempuan), wali dari calon pengantin perempuan, terdapat dua orang sebagai saksi pernikahan, dan Ijab Qobul (Shofiyah, 2014); (Surya, 2020). Berbagai syarat tersebut sebagai rukun atau sering disebut syarat wajib yang harus ada dalam pernikahan. Selain itu, terdapat pula sunahnya antara lain adanya khutbah nikah, 
pengumuman pernikahan melalui perayaan, dan menyebutkan sejumlah mahar pernikahan (Adillah, 2016); (Supriyadi, 2018).

Oleh karena itu dalam perkawinan yang tidak tercatat pemerintah (sirri) yang dilaksanakan yaitu hanya berupa rukun nikahnya, sedangkan untuk sunahnya tidak dilakukan, terutama tentang pengumuman atau perayaan pernikahan tersebut. Dengan demikian, hanya beberapa orang dan kalangan saja yang mengetahui atas pelaksanaan pernikahan sirri tersebut (Alfin \& Busyro, 2017).

Perkawinan yang tidak tercatat pemerintah (sirri) ini tentunya hanya bisa dilaksanakan jika kedua calon pengantin telah memenuhi baik syarat maupun rukun sahnya perkawinan ditinjau menurut Hukum Islam. Jika syarat serta rukun perkawinan sudah dapat terpenuhi, perkawinan baru bisa dilaksanakan, kemudian setelah ijab qabul, keduanya sudah dinyatakan sah menjadi pasangan suami istri secara agama, meskipun tidak dilakukan pencatatan ke pemerintah sebagaimana yang telah diatur melalui Undang-undang tentang perkawinan di negara Indonesia tercinta. Namun sebagai warga negara yang baik, tentunya kita memiliki kewajiban mentaati ketentuan-ketentuan hukum positif yang ada.

Ketentuan dan sistem hukum di negara kita tidak mengenal istilah perkawin sirri serta tidak mengatur secara khusus. Namun, secara sudut pandang sosiologis, istilah tersebut diberikan terhadap perkawinan yang tidak dilakukan pencatatan kepada pemerintah dan dianggap tidak memenuhi ketentuan yang ada terutama undang-undang negara kita Pasal 2 ayat (2) UndangUndang Perkawinan (Supriyadi, 2018).

Undang-undang Nomor 1 Tahun 1974 merupakan fondasi atau dasar hukum perkawinan yang digunakan di Indonesia, tentunya undang-undang tersebut berlaku bagi setiap WNI tanpa pandang bulu. Berdasarkan dari penjelasan Pasal 2 ayat (1) yaitu tidak ada perkawinan di luar hukum masing-masing agama dan kepercayaannya. Berdasarkan uraian di atas, tampak jelas bahwa perkawinan yang tidak tercatat pemerintah (sirri) masih diakomodir dalam undangundang tersebut, sehingga cukup banyak masyarakat kita melakukan perkawinan sirri hingga saat ini dan tidak mencatatkannya ke pemerintah melalui KUA (Islam) atau lembaga lain dari masing-masing agama (non Islam) yang ditunjuk oleh pemerintah (Surya, 2020).

Berdasarkan pada pernyataan dan ketentuan di atas, maka dapat pahami serta dimengerti bahwa perkawinan yang tidak tercatat oleh pemerintah (sirri) secara pandangan agama maupun pandagan adat istiadat dianggap legal dan sah, akan tetapi perkawinan semacam ini yang dilakukan tanpa adanya pencatatan nikah oleh petugas yang ditunjuk pemerintah tidak mempunyai kekuatan secara hukum serta dianggap tidak sah pula dimata hukum itu sendiri. Hal itu dapat dilihat berdasarkan ketentuan yang terdapat pada Pasal 2 ayat 2 tentang UndangUndang Perkawinan, yang bunyinya sebagai berikut "Tiap-tiap perkawinan dicatat menurut peraturan perundang-undangan yang berlaku". Pada pasal tersebut pada intinya untuk memberikan kepastian hukum atas status perkawinan serta memberikan perlindungan hukum kepada pihak perempuan dalam hal ini yaitu istri serta anak atas perkawinan yang dilakukan kedua mempelai (Islami, 2017); (Adillah, 2016); (Supriyadi, 2018).

Secara umum terjadinya perkawinan yang tidak tercatat pemerintah (sirri) memiliki latar belakang faktor ekonomi (terutama perempuan). Banyak perempuan belum cukup umur bahkan terpaksa dinikahkan oleh orang tua mereka dengan harapan dapat mengurangi beban ekonomi 
keluarga karena kemiskinan. Selain faktor ekonomi yang sering menjadi latar belakang terjadinya perkawinan yang tidak tercatat pemerintah (sirri) yaitu faktor pendidikan. Banyak masyarakat ketika anak mereka lulus dari SD atau SMP dipaksa menikah bahkan usianya masih dibawah umur dengan melanggar ketentuan pemerintah (Islami, 2017); (Adillah, 2016).

Dampak dari perkawinan yang tidak tercatat pemerintah (sirri) bagi perempuan secara hukum yaitu dianggap bukan istri secara sah, tidak memiliki hak atas nafkah maupun warisan (suami meninggal) dan harta gono gini (jika cerai). Sementara dampak atau akibat perkawinan yang tidak tercatat pemerintah (sirri) bagi anak yaitu dianggap bukan anak sah dimata hukum termasuk hak-hak atas ekonomi sang anak selanjutnya yang akan berpengaruh pula terhadap kemampuan pendidikan sang anak kelak dalam membiayai pendidikannya tersebut nantinya, yang pada akhirnya akan menciptakan generasi yang fakir dan minim pendidikan. Oleh karena itu, agar hal tersebut tidak terjadi pemerintah memberikan aturan sesuai Pasal 2 pada ayat 2 UU Nomor. 1 Tahun 1974 bahwa setiap perkawinan harus dicatat menurut ketentuan perundangundangan yang berlaku (Supriyadi, 2018); (Surya, 2020).

Oleh karena itu, peran pemerintah dan segenap masyarakat dalam mengedukasi tentang dampak kawin dibawah tangan (sirri) yang begitu besar efeknya terhadap ekonomi sangat diperlukan setiap saat agar generasi kita dilindungi secara hukum atas hak-hak ekonominya meskipun orang tua mereka bercerai yang diakibatkan oleh beberapa hal nantinya.

\section{Kesimpulan}

Berdasarkan hasil penelitian dapat disimpulkan bahwa perkawinan yang tidak tercatat oleh pemerintah memiliki dapak hukum yang besar terutama terhadap harta benda hasil pernikahan, terhadap status anak hasil perkawinan. Perkawinan ini sah dimata agama tetapi tidak memiliki kekuatan hukum yang dapat merugikan pihak perempuan maupun anak, karena tidak dapat melakukan tuntutan secara hukum terhadap suami ketika sang suami tidak memberikan nafkah serta suami menceraikan istrinya, dan bahkan tidak berhak atas harta warisan jika suaminya meninggal. Tentunya secara dampak ekonomi bagi istri apalagi terhadap anak keturunan mereka sangat besar. Suami atau sang ayah dari anak tersebut dapat meninggalkan semua kewajiban atas segala biaya hidup baik terhadap mantan istri maupun anak yang telah ditinggalkannya. Dengan demikian yang akan menjadi korban ekonomi paling besar justru terhadap anak keturunan mereka dipandang dari sisi hukum.

\section{Daftar Pustaka}

Adillah, S. U. (2016). Implikasi Hukum Dari Perkawinan siri Terhadap perempuan dan anak. Palastren Jurnal Studi Gender, 7(1), 193-222.

Alfin, A., \& Busyro, B. (2017). Nikah Siri dalam Tinjauan Hukum Teoritis dan Sosiologi Hukum Islam Indonesia. Al-Manahij: Jurnal Kajian Hukum Islam, 11(1), 61-78.

Asmaya, E. (2012). Implementasi agama dalam mewujudkan keluarga sakinah. Komunika: Jurnal Dakwah dan Komunikasi, 6(1). 
Badri, M. A. (2017). Korelasi Antara Pernikahan Dengan Perdamaian Sosial Masyarakat (Studi Kasus Terhadap Pernikahan Nabi Muhammad dengan Juwairiyah Binti Al Haris dan Ummu Habibah Binti Abi Sufyan). Al-Majaalis, 5(1), 201-231.

Brake, E. (2011). Minimizing marriage: Marriage, morality, and the law. Oxford University Press.

Faizah, S. (2014). Dualisme Hukum Islam di Indonesia tentang Nikah Siri. Istidal: Jurnal Studi Hukum Islam, 1(1).

Fitrianti, D. (2017). Harta Bersama dalam Perkawinan Poligami Menurut Undang-Undang Nomor 1 Tahun 1974 dan Hukum Islam. Jurnal Intelektualita: Keislaman, Sosial dan Sains, 6(1), 83-102.

Islami, I. (2017). Perkawinan di Bawah Tangan (Kawin Sirri) dan Akibat Hukumnya. Adil: Jurnal Hukum, 8(1), 69-90.

Masduqi, I. (2013). Nikah Sirri dan Istbat Nikah dalam Pandangan Lembaga Bahtsul Masail PWNU Yogyakarta. Mus ,, wa Jurnal Studi Gender dan Islam, 12(2), 187-200.

Rodliyah, N. (2014). Akibat Hukum Perceraian Berdasarkan Undang-Undang Nomor 1 Tahun 1974 Tentang Perkawinan. Keadilan Progresif, 5(1).

Saebani, B. A. (2008). Perkawinan dalam hukum Islam dan undang-undang: perspektif fiqh munakahat dan UU no. 1/1974 tentang poligami dan problematikanya. Pustaka Setia.

Shofiyah, S. (2014). Nikah Sirri Dan Urgensi Pencatatan Perkawinan. Madinah: Jurnal Studi Islam, 1(2), 109-117.

Subekti, T. (2010). Sahnya Perkawinan Menurut Undang-Undang Nomor 1 Tahun 1974 Tentang Perkawinan Ditinjau Dari Hukum Perjanjian. Jurnal Dinamika Hukum, 10(3), 329-338.

Suhartatik, S. (2013). Konsep poligami Rasulullah SAW sebagai strategi dakwah Islam (Doctoral dissertation, IAIN Walisongo).

Supriyadi, S. (2018). Perkawinan Sirri dalam Perspektif Hukum di Indonesia. Yudisia: Jurnal Pemikiran Hukum dan Hukum Islam, 8(1), 1-17.

Surya, H. (2020). Problematika Nikah Sirri di Indonesia (Kedudukan Nikah Sirri Menurut Hukum Positif Indonesia). AL-ILMU, 5(1).

Wibisana, W. (2016). Pernikahan dalam islam. Jurnal Pendidikan Agama Islam-Ta'lim. 